\title{
BOTHROPS JARARACUSSU: A NEW RECORD FOR THE MUNICIPALITY OF SÃO PAULO, BRAZIL
}

\author{
Silara Fatima Batista1 \\ Maísa Assano Matuoka² \\ Jade Lima-Santos ${ }^{3}$ \\ Priscila Maria Roswell ${ }^{4}$ \\ Otavio A. V. Marques ${ }^{5}$
}

Abstract - Bothrops jararacussu is a terrestrial snake, predominantly nocturnal, and mainly found in forested areas. Our objective was to provide the first record of B.jararacussu for the municipality of São Paulo, in the highland of Parque Estadual da Serra do Mar (PESM), Núcleo Curucutu. The register ocurred through monthly samplings in the Núcleo Curucutu, during one year. The specimen was found in a transitional area of Atlantic upper montane forest and Pinus sp. reforestation. It represents a new altitude record $(>800 \mathrm{~m})$ in a well-preserved area, reiterating the importance of this park for the maintenance of biodiversity in this municipality and evinces the region potential to house rare species in São Paulo highland.

Key- words: Bothrops jararacussu; geographic distribution; São Paulo; Serra do Mar

\footnotetext{
'Departamento de Zoologia e Botânica, Universidade Estadual Paulista, Rua Cristóvão Colombo, 2265, São José do Rio Preto, SP, CEP 15045-000, Brazil. E-mail: silara.batista@butantan.gov.br.

${ }^{2}$ Laboratório de Ecologia e Evolução, Instituto Butantan, Av. Vital Brazil, 1500, São Paulo, SP, CEP 05503-900, Brazil. E-mail: maisa.matuoka@butantan.gov.br.

${ }^{3}$ Laboratório Especial de Coleções Zoológicas, Instituto Butantan, Av. Vital Brazil, 1500, São Paulo, SP, CEP 05503-900, Brazil. E-mail: jade.santos@butantan.gov.br.

${ }^{4}$ Laboratório de Ecologia e Evolução, Instituto Butantan, Av. Vital Brazil, 1500, São Paulo, SP, CEP 05503-900, Brazil. E-mail: priscila.roswell@butantan.gov.br.

${ }^{5}$ Laboratório de Ecologia e Evolução, Instituto Butantan, Av. Vital Brazil, 1500, São Paulo, SP, CEP 05503-900, Brazil. E-mail: otavio.marques@butantan.gov.br.
} 